\title{
Solar Desalination using CPC and Heat Pipe
}

\author{
Gayatri A Shahane $^{1}$, Ayushi A Jain ${ }^{2}$, C.P. Waykole ${ }^{3}$ \\ Student, Mechanical Engineering, M.I.T College of Engineering, Pune, India ${ }^{1,2}$ \\ Assistant Professor, Mechanical Engineering, M.I.T College of Engineering, Pune, India ${ }^{3}$
}

\begin{abstract}
In India as well as around the world there is abundance of water but scarcity of potable or usable water. The basic idea of the project is convert unusable sea water into desalinated water using renewable energy. To get the desired results we have used a Compound Parabolic Concentrator (CPC) which focuses the solar energy. A heat pipe is combined with the CPC to maximise the efficiency.
\end{abstract}

Keywords: Compound Parabolic Concentrator (CPC), Heat Pipes, Desalination, Solar Energy.

\section{INTRODUCTION}

Increasing population demands for more usable water. loses. It can reduce the required solar cell area by four Scarcity of water is a major common problem. There are times, depending on the angle of acceptance. Moreover, quite a few water purification techniques like Reverse CPC is a concentrator which does not require solar Osmosis (RO), filtration, sedimentation, chlorination etc. tracking.

These techniques are often expensive and non-ecofriendly.

Solar Energy is one of the most abundantly available green energy sources. It is harnessed using various techniques like solar panels, solar cells, photovoltaic cells etc.

As we know, the need of the hour is maximum use of clean and renewable energy sources. There is a necessity to develop a technique which uses renewable energy (solar energy) for water desalination.

Hence, we have come up with a solution which integrates solar energy with water purification using Compound Parabolic Concentrators with Heat Pipes.

\section{DESCRIPTION}

\section{A. Field of Experiment}

The project includes the use of CPC combined with a Heat Pipe to desalinate water used for residential purposes.

\section{B. Methodology}

The sunrays get concentrated in the CPC at its base. This heat which is generated further heats the liquid solution in the heat pipe. The heat pipe is placed slanting at the base of the CPC. The heated solution from the heat pipe goes to the insulation box, where the sea water is kept.

Heat exchange takes place in the insulation box and the sea vaporises. These vapours are further condensed, thus we get pure distilled water.

\section{Major Components Used}

- Compound Parabolic Concentrator

Considering the size and concentration ratio of the CPC we selected the angle of acceptance to be 30 degrees. Material selected is lexan polycarbonate corrugated sheet. It has excellent light transmission, uniform light diffusion, and is both sides UV coated. More importantly it is easy to manufacture into a CPC.

\section{- Heat Pipe}

A heat pipe is a device which allows high heat transfer with minimum loses. The choice of the operating liquid depends on the operating temperature range and material compatibility.

For example, water with copper, ammonia with aluminium, etc. The approximate temperature range for various operating fluids is

$$
-\mathrm{H}_{2} \mathrm{O}\left(30-200^{\circ} \mathrm{C}\right), \mathrm{Na}\left(600-1200^{\circ} \mathrm{C}\right), \mathrm{NH}_{3}\left(-60-100^{\circ} \mathrm{C}\right) \text {. }
$$

\section{- Heat Exchanger Box}

In theheat exchanger box the sea water gets evaporated due to the heat exchange taking place between the heat pipe and sea water.

This vapour is further condensed to form pure distilled water. The residue of salts and other contaminants are collected in a separate tray. The insulating material prevents heat losses.

\section{- Biomass Gasifier}

A biomass gasifier converts solid biomass into heat by certain chemical processes. The advantage of a biomass gasifier is that it produces clean energy.

During the period of year when the sunlight is weak a CPC is an efficient solar energy collector. It concentrates a biomass gasifier can be used as a secondary source so that large amount of sunlight in small area with minimum 
The following figure shows the basic layout of the setup

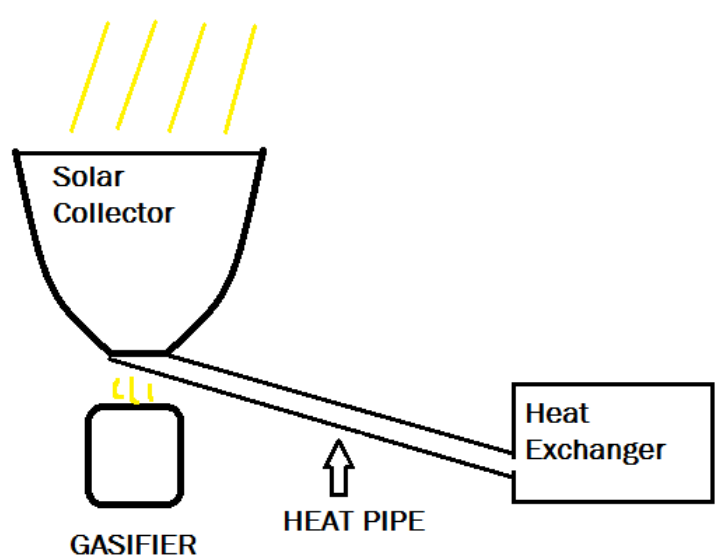

Fig.1 Basic Layout of the Setup

\section{CONCLUSION}

A CPC and Heat Pipe based system thus is a effective use of renewable energy to obtain desalinated water. This is done without the use of electricity and thus can be used in rural and coastal parts of the country.

\section{REFERENCES}

[1] A.G. Bhave ,International Journal of Modern Engineering Research (IJMER) Vol.2, Issue.5, Sep-Oct. 2012 pp-3800-3802

[2] Amitava Bhattacharyya, International Journal of Environment and Sustainability,' Solar Stills for Desalination of Water in Rural Households', Vol. 2 No. 1, pp. 21-30 (2013).

[3] K.N.Shukla, Journal of Electronics Cooling and Thermal Control, 2015, 5, 1-14,Heat Pipe for Aerospace Applications-An Overview, March 2015

[4] Leon Lung-Chen Chen, May 2002, Solar compound concentrator of electric power generation system for residential homes,US6384320 B1

[5] OPTIS White Paper 1008 Solar CPC

[6] Soteris A. Kalogirou ,Progress in Energy and Combustion Science 31 (2005) 242-281,Seawater desalination using renewable energy sources ,Department of Mechanical Engineering, Higher Technical Institute, P.O. Box 20423, Nicosia 2152, Cyprus ,Received 7 July 2004; accepted 17 March 2005 